\title{
THE EFFECT OF IBA AND CUTTING DIAMETER ON INDUCING ROOTS OF COTINUS COGGYGRIA SCOP. AND RHUS CORIARIA L. (ANACARDIACEAE)
}

\author{
Hassan Najman Muhamed ${ }^{\mathrm{a}, *}$, and Nasser Abdusalam Dawod ${ }^{\mathrm{b}}$ \\ a Dep. of forestry, College of Agriculture, University of Duhok, Kurdistan Region, Iraq - hassan.muhamed@uod.ac \\ ${ }^{\mathrm{b}}$ Directorate of forestry and rangelands, Duhok, Kurdistan Region, Iraq
}

\begin{abstract}
:
Because of the difficulty in their vegetative propagation, both Rhus coriaria L. and Cotinus coggygria Scop. (Ancardaceae) are rarely introduced into the forest nursery trade. Vegetative propagation is practiced in forestry to produce seedlings of desired genetic properties within a short period and when seeds displaying a status of complex dormancy. In the present study, the possibility of the multiplication by stem cuttings was studied for Sumac, the high ethnobotanical shrub value and for Cotinus, the endangered shrub, to give more insight into their propagation technique. Between January-July 2014, using complete randomized block design (C.R.B.D) in four replicates, we evaluated the effectiveness of applying four different Indole-3-Butyric Acid (IBA) concentration to two stems cutting diameters in producing $C$. coggygria and $R$. coriaria. However, the former species due to the poor survival percentage (lower 5\%) excluded from the analysis. Optimum results of C. coggygria were obtained with IBA 20000 mg. $1^{-1}$ and cutting diameter more than $1 \mathrm{~cm}$. (rooting \% 60, number of roots 17.33 , number of branches 3.75 and the number of leaves 19.33 while nonsignificant increase was recorded in root length. $16.33 \mathrm{~cm}$.). The results indicated that Cotinus is relatively easy to propagate by stem cutting in comparing with Sumac with rootability increases significantly with increasing of IBA concentration and stem cutting diameter. Further studies are needed for more reasonable rooting results to meet the large quantity demand of elite seedling material that could be later used to restore the natural populations of C. coggygria and $R$. coriaria.
\end{abstract}

KEYWORDS: Sumac, Cotinus, Rooting, Stem cuttings, Vegetative propagation, IBA.

\section{INTRODUCTION}

There is an urgency to develop measures for restoration of depleted natural populations. The reproductive success of the endangered shrubs or those difficult to propagate sexually recently became concerned by nurserymen (Deepak et al., 2015). Vegetative propagation considered a conservation way of those species which are economically and ecologically important and difficult to grow from seed and other reproductive means in forest nurseries, for most tree species, the sexual propagation takes longer time to get plantable seedling size and doesn't guarantee the same traits of donor plant (Barbuti et al., 2012).

Vegetative propagation is commonly used with species that have short and low seed viability, or hard seed dormancy. All new produced individuals from vegetative propagation are genetically a copy of the donor plant. The uses of stem cuttings are considered the most applied technique due to its practicability and simplicity for mass production within a short time (Yong and Ki, 1996). However, the rooting ability of cuttings varies with species and types of cuttings (Hartmann et al., 2002). In the vegetative propagation, the rooting process plays a key role, where poor rooting causes considerable losses in the propagation industry. This is can be critical, particularly with rare and endangered species where small of plant material can be available.

It has long been known that adventitious roots develop in cuttings influenced by auxins. Usually, Indole-3-Butyric Acid (IBA) auxin is recommended to promote the produce of adventitious roots in cuttings of shrubs (Kaul, 2008 and Husen and Khatoon, 2012). Furthermore, a large body of articles recommended that the root initiation and survival rates can be increased by applying endogenous rooting hormones before plantation. Tracz (1983) reported that rooting and sprouting of Rhus aromatica Ait. was more after treatment with 1 g/l IBA. Nokes (1986) also displayed that semi-hardwood cutting of evergreen Sumac treated with an auxin-talc preparation of $0.8 \mathrm{~g} / 1$ IBA has rooted better than control. Tipton (1992) recorded (24\%) rooting percentage of Rhus virens cuttings taken 16 weeks after bud break and treated with 5 gl-1 of IBA. Pacholczak et al., (2013) found that IBA positively affects rhizogenesis in Cotinus coggygria in conventional stem cuttings and in microcuttings. In same line Dunn (1999) found that $C$. coggygria softwood cuttings under glass house condition had $92 \%$ when took in 25 May and treated with $10000 \mathrm{ppm} \mathrm{IBA+5000}$ NAA quick dip with a number of roots 51.5 and average of longest three roots $13.9 \mathrm{~cm} ., 20000 \mathrm{ppm}$ IBA reduce the rooting capacity, indicating the negative effect of high auxin concentration.

Researchers have correlated the survival rate of some species with the amount of the accumulated starch in the cuttings. High amounts of starch result in more energy for the growing roots and thus better survival rates. Hartman et al., (2002) and Muhamed and Sarhan (2016) they attributed such effect to the size of the used cuttings and the number of the presence of vegetative buds. An understanding of the factors affecting the rootability of stem cuttings such as cutting size and response to auxins is essential (Hartmann et al., 2002). Hence, this study was intended to show the effects IBA application and stem cutting diameter on the rootability of Sumac harder to root and germinate shrub and Cotinus the endangered shrub for reintroducing them later into depleted natural population's sites.

\footnotetext{
* Corresponding author
} 


\section{MATERIALS AND METHODS}

\subsection{Study species}

Sumac (Rhus coraria L.) and Smoke tree (Cotinus coggygria Scop.) both are species of the cashew family (Anacardiaceac). Sumac is a shrub used in pharmaceutical preparation, food coloring and preservations. Sumac is a shrub with a long history application in traditional medicine and Kurdish cuisine (Shahbaz, 2010; Mohammadi et al., 2010). Ecologically, this species is well known in controlling soil erosion where root system tends to be shallow and widespreading conserving soil on sloping sites (Ogle et al., 2000). C.coggygria. is a multi-stemmed shrub. It is cultivated primarily for landscape purposes because of its ornamental features like purple foliage and flowers and its adaptability to widely divergent soils and $\mathrm{pH}$ ranges (Dirr, 1990). Vegetative propagation of this species by conventional cutting, although used, can be slow, difficult, and cultivar-dependent. Shahbaz (2012) listed C. coggygria as an endangered species existing as small and isolated populations in Babery -Duhok area under climate and human disturbances. The durable wood of $C$. coggygria has been used for fence posts. Also, this species have antiinflammatory, antibacterial, and wound-healing properties (Tsankova et al., 1993).

\subsection{Treatments and experiment design}

The study was carried out in a plastic house in Malta nursery - Directorate of Forests and Rangelands-Duhok, Kurdistan Region- Iraq (N36॰ 51' 28", E42॰ 51'06") during 14 January to 22 July 2014. The hardwood cuttings of Cotinus coggygria were taken from mother shrubs (diameter $8-10 \mathrm{~cm}$ ) in a very limited locality of about 1 square $\mathrm{km}$ in the Baberey village (N 37 11.836, E 43 11.423), at an elevation range of 864.1, $999.79 \mathrm{~m}$, along the upper side of the road on a steep slope of a northern exposure. The hardwood cuttings of Rhus coriaria $\mathrm{L}$ were collected from parent shrubs naturally distributing in Warmely village (N 37 11.43, E 43 11.28).The cuttings of both species were prepared with a length of $20 \mathrm{~cm}$ containing 4-5 buds and given slanting cut at base end, then the cuttings sorted out according to two thicknesses (1-2 cm diameter) and small sized $(0.5$ - less than $1 \mathrm{~cm}$ diameter) using a digital caliper. The bases of Rhus coriaria L cuttings were wounded longitudinally with the length of $2 \mathrm{~cm}$; two opposite wounds for each cutting end. The bases of all cuttings were treated with four concentrations of IBA solution $(0,10.000,15.000$, and $20.000 \mathrm{mg} 1-1)$ where dipped quickly for $10 \mathrm{~s}$. After that planted $15 \mathrm{~cm}$ deep into the soil at a spacing of $10 \mathrm{~cm} \times 10$ $\mathrm{cm}$ in high nursery beds under semi-controlled conditions of a plastic house. A light overhead watering was given immediately after planting so that cuttings get settled. Afterwards, the planted cuttings were irrigated regularly as and when required.

The cuttings were removed after 23 weeks of planting beds and the experimental measurements were recorded as follows:

1. Rooting percentage (\%).

2. Root's number/ cutting.

3. Root's length $(\mathrm{cm})$.

4. Branches number

5. Leaves number / cutting.

The experiment was applied by using Randomized Complete Block Design (R.C.B.D) with two factors in four replicates. Each replicate included eight cuttings. The angular conversion was done for the results of rooting percentage then analyzed statistically by using SAS program. Mean values were compared by Duncan test at 0.05 level (SAS,
2001) regardless of the significance of ANOVA test (Al-Rawe and Khalaf, 1980).

\section{RESULTS}

Due to the poor obtained results from Sumac stem cuttings which almost less than 5\% it's excluded from the analysis. Generally, from the findings, it has been found that IBA concentrations had a significant effect on the rooting capacity of Cotinus stem cuttings. The size of the cuttings represented by the diameter has shown also a significant correlation with the percentage of sprouted root cuttings. In this experiment, it was visually noted that all the emerged roots were generated from the buried buds not from the cutting bases.

Duncan's test in table (1) showed that applying auxin significantly influenced most rooting traits, the values increased with increasing the IBA concentrations up to $20000 \mathrm{mg} . \mathrm{l}^{-1}$ IBA compare to non-treated cuttings. The higher values have been recorded were R\%, NR, NB and NL (54.16\%, 16.65, 3.02 and 16.3) respectively, with no significance increasing in the root length RL over all the used IBA.

Table 1. Effect of IBA on rooting and vegetative characteristics of hard

\begin{tabular}{|c|c|c|c|c|c|}
\hline $\begin{array}{l}\text { IBA } \\
\text { concentrations } \\
\text { mg.l }^{-1}\end{array}$ & $\begin{array}{c}\text { Rooting } \\
\text { percentage } \\
\%\end{array}$ & $\begin{array}{c}\text { Roots } \\
\text { numbers }\end{array}$ & $\begin{array}{l}\text { Roots } \\
\text { Length } \\
\text { (cm) }\end{array}$ & $\begin{array}{l}\text { Branches } \\
\text { number }\end{array}$ & $\begin{array}{l}\text { Leaves } \\
\text { number }\end{array}$ \\
\hline control & $15.333 \mathrm{~d}$ & $9.333 \mathrm{~d}$ & $\begin{array}{c}13.667 \\
\text { a }\end{array}$ & $2.25 \mathrm{~b}$ & $\begin{array}{c}12.958 \\
\mathrm{~b}\end{array}$ \\
\hline 10,000 & $31.167 \mathrm{c}$ & $12.291 \mathrm{c}$ & $\begin{array}{c}14.388 \\
\mathrm{a}\end{array}$ & $2.855 \mathrm{a}$ & $\begin{array}{c}14.368 \\
\text { ab }\end{array}$ \\
\hline 15,000 & $41.25 \mathrm{~b}$ & $14.166 \mathrm{~b}$ & $15.82 \mathrm{a}$ & $2.583 \mathrm{ab}$ & $\begin{array}{c}14.958 \\
\text { ab }\end{array}$ \\
\hline 20,000 & $4.167 \mathrm{a}$ & $6.625 \mathrm{a}$ & 16.167 & $3.0217 \mathrm{a}$ & 16.375 \\
\hline
\end{tabular}

Similar trends were obtained with the used diameters of stem cuttings; generally the rooting increased with increasing cutting stem diameters from less than $1 \mathrm{~cm}$ to up to $2 \mathrm{~cm}$. The Duncan test in table (2) showed a significant difference for most measured parameters between the diameters of stem cuttings. The cuttings with more than $1 \mathrm{~cm}$ diameter produced significantly higher $\mathrm{R} \%$, $\mathrm{NB}$, and NL (38.8\%, 3.35 and 17.57 respectively). However, both NR, RL did not differ significantly.

Table 2. Effect of cutting diameter on rooting and vegetative characteristics of hardwood stem cuttings of Cotinus coggygria

\begin{tabular}{|c|c|c|c|c|c|}
\hline Treatments & $\begin{array}{c}\text { Rooting } \\
\text { percentage } \\
\%\end{array}$ & $\begin{array}{c}\text { Roots } \\
\text { numbers }\end{array}$ & $\begin{array}{l}\text { Roots } \\
\text { Length } \\
\text { (cm) }\end{array}$ & $\begin{array}{l}\text { Branches } \\
\text { number }\end{array}$ & $\begin{array}{l}\text { Leaves } \\
\text { number }\end{array}$ \\
\hline $\begin{array}{l}\text { Cutting } \\
\text { diameter } \\
\text { less than } 1 \\
\mathrm{~cm}\end{array}$ & $32.125 \mathrm{~b}$ & $\begin{array}{c}12.9167 \\
\mathrm{a}\end{array}$ & $\begin{array}{c}14.4375 \\
\mathrm{a}\end{array}$ & $2 \mathrm{~b}$ & $\begin{array}{c}11.757 \\
\mathrm{~b}\end{array}$ \\
\hline $\begin{array}{l}\text { Cutting } \\
\text { diameter } \\
\text { more than } \\
1 \mathrm{~cm}\end{array}$ & $38.833 \mathrm{a}$ & $\begin{array}{c}13.2917 \\
\mathrm{a}\end{array}$ & $\begin{array}{c}15.5833 \\
\mathrm{a}\end{array}$ & $3.3542 \mathrm{a}$ & $\begin{array}{c}17.573 \\
\mathrm{a}\end{array}$ \\
\hline
\end{tabular}

The interaction effects of both IBA concentrations and stem cutting diameters significantly magnified the values of the most studied parameters except root length. All of the parameters value increased with increasing the IBA concentrations up to 20000 mg. $1^{-1}$ IBA and stem cutting diameter more than $1 \mathrm{~cm}$. the values were R\% 60, NR 17.33, NB 3.75 and NL 19.33 while no significant differences were found for RL $16.33 \mathrm{~cm}$ (Table 3).

\section{DISCUSSION}

Vegetative propagation is important for the preservation of both Rhus corriaria and Cotinus coggygria species, particularly in depauperate populations, with low seed set and have a deep dormancy that causing slow and irregular germination. 
Table 3. Effect of the interaction treatments between cutting diameter and IBA on rooting and vegetative characteristics of hardwood stem

\begin{tabular}{|c|c|c|c|c|c|c|}
\hline Treatments & $\begin{array}{l}\text { IBA concentrations } \\
\mathrm{mg.l}^{-1}\end{array}$ & $\begin{array}{c}\text { Rooting percentage } \\
\%\end{array}$ & $\begin{array}{c}\text { Roots } \\
\text { numbers }\end{array}$ & $\begin{array}{l}\text { Roots Length } \\
\text { (cm) }\end{array}$ & $\begin{array}{l}\text { Branches } \\
\text { number }\end{array}$ & $\begin{array}{c}\text { Leaves } \\
\text { number }\end{array}$ \\
\hline \multirow{4}{*}{$\begin{array}{l}\text { Cutting diameter less } \\
\text { than } 1 \mathrm{~cm}\end{array}$} & control & $13.167 \mathrm{~d}$ & $8.75 \mathrm{f}$ & $14 \mathrm{ab}$ & $1.583 \mathrm{~d}$ & $8.83 \mathrm{~d}$ \\
\hline & 10000 & $30.167 \mathrm{c}$ & $12.583 \mathrm{de}$ & $12.11 \mathrm{~b}$ & $2.21 \mathrm{~cd}$ & $11.443 \mathrm{~cd}$ \\
\hline & 15000 & $36.833 \mathrm{c}$ & $14.416 \mathrm{~b}$ & $15.64 \mathrm{ab}$ & $1.9167 \mathrm{~d}$ & $13.33 \mathrm{bc}$ \\
\hline & 20,000 & $48.333 \mathrm{~b}$ & $15.916 \mathrm{~b}$ & $16 \mathrm{ab}$ & $2.293 \mathrm{~cd}$ & $13.417 \mathrm{bc}$ \\
\hline \multirow{4}{*}{$\begin{array}{l}\text { Cutting diameter more } \\
\text { than } 1 \mathrm{~cm}\end{array}$} & control & $17.5 \mathrm{~d}$ & $9.917 \mathrm{f}$ & $13.3 \mathrm{ab}$ & $2.9167 \mathrm{bc}$ & $17.083 \mathrm{ab}$ \\
\hline & 10,000 & $32.167 \mathrm{c}$ & $12 \mathrm{e}$ & $16.667 \mathrm{a}$ & $3.5 \mathrm{ab}$ & $17.29 \mathrm{ab}$ \\
\hline & 15,000 & $45.667 \mathrm{~b}$ & $13.916 \mathrm{~cd}$ & $16 \mathrm{ab}$ & $3.25 \mathrm{ab}$ & $16.583 \mathrm{ab}$ \\
\hline & 20,000 & $60 \mathrm{a}$ & $17.33 \mathrm{a}$ & $16.333 \mathrm{ab}$ & $3.75 \mathrm{a}$ & $19.33 \mathrm{a}$ \\
\hline
\end{tabular}

\subsection{Rhus corriaria}

The poor rootability results of sumac (below $5 \%$ survival) at the end of the experiment did not allow to running the statistical analysis, therefore this species excluded from the analysis. The poor rooting of sumac stem cuttings can be understandable; this species is well known as a hard to root species. There is a general agreement that the lack of the rootability of Anacardaceae species is due to the presence of extensive resin that usually flow from the bases of prepared cuttings, such extract resin could physically cause significant inhibition of the stem cuttings rootablity (Edwards and Thomas, 1980). Despite the fact that the wounding treatments in certain species increase the penetration of IBA by breaking the sclerenchyma bands that constitute a mechanical barrier for callus formation and emerging adventitious root primordia (see Wilson and Grange, 1983 and Oezkaya, 1998), wounding treatment did not serve such function under our experimental conditions likely for one or both of the following reasons: first, the wounding maybe increase the bleeding of the resin and formed an impenetrate solid ring around the base of the cutting lead to unattached the IBA and prevent it to act properly, second, the wounding was just slightly made where some researchers believe that in hard to root woody species such barriers can only overcome by making a deep wounding or splitting the base of the cuttings (Newman, 2014).

Indeed, our results are in line with previous studies showed poor outcome of sumac stem cuttings e.g., Porter (1963) with Rhus lancea $31.7 \%$ at 4000 ppm IBA, Tipton (1992), with Rhus virens $24 \% 5000 \mathrm{ppm}$ IBA and more recently Media (2016) who found maximum rooting percentage 11.67 when cuttings treated with 15000 IBA in media of Sand + Sandy loam + Peat moss) with the proportion of $(2: 1: 1)$.

\subsection{Cotinus coggygria}

There is some urgency to conduct experiments dealing with the propagation technique for the restoration of depleted natural populations, finding a way to produce good quality seedlings, later can be used to restore natural populations of Cotinus was the objective of this experiment. However, because of the low population of Cotinus in Babery site (the only site where this species coexist) represented by the small number of disturbed shrubs due to human interference (heavily pruned were shown on the shrubs) it was not possible to enlarge the size of this experiment by increasing the number of the study factors or increase the factor levels. Therefore, we considered that our experiment a first attempt to gain information may help to increase the propagation of this endangered species. According to Leakey (2004), internal and external factors governing root intonation. Auxins play a critical role in the formation and increasing initiation of the root primordium and growth via cell division (Fogaca and Fett-Neto 2005). Auxins stimulate starch hydrolysis and drive sugars and nutrients to the cutting base (Das et al., 1997).
The significant influence of IBA in rooting ability and growth of Cotinus cuttings was expected since IBA is well-known as a root promoter in cuttings of many shrubs (Husen and Mishra, 2001 and Hartmann et al., 2002). IBA auxin normally acts by signaling the proteins to stimulate new cell and resulting in the initiation of numerous lateral roots (Saifuddin et al., 2003). In the context of root initiation, it is worth to mention that we observed that all the initiated roots were emerged from the buried buds of cuttings not from the cutting base, almost because of the physical barrier that formed from the bleed resin at cuttings bases which is common in Anacardiaceae. (Macdonald, 1986).

In this experiment we considered the cutting diameter alone (Burgess et al., 1990; Foster et al., 2000). The results showed that the cutting diameter significantly influenced the rooting ability in Cotinus. The optimum rooting results were obtained for thicker cuttings (cuttings of more $1 \mathrm{~cm}$ diameter). This is in line with Doroudi et al., (2008) who found that the best result can be obtained for Rhus corriaria stem cuttings by use of high diameter cuttings in sand. See also Burgess et al., (1990) in Salix alba; Foster et al (2000) in Loblolly pine and OuYang et al., (2015) in Picea abies. Initial cutting size is considered as an important factor influencing the rooting ability and growth performance, cuttings with a larger diameter result in better survival and growth under normal conditions (Leakey 1983; Hannerz et al., 1999; Vigl and Rewald 2014). Leakey and Mohammed (1985) found that Triplochiton scleroxylon cuttings of the same length but largest diameter have the greatest rooting percentages, indicating that cutting storage capacity represented by diameter may be more critical than length. The effectiveness of rooting by larger cuttings can be attributed to the level of endogenous auxins which may be lower in smaller cuttings lead to reduced rooting percentage (Palanisamy and Kumar, 1997), or larger cuttings store more stem carbohydrates (Tchoundjeu and Leakey, 1996). However, Muhamed and Sarhan (2016) found contrast that finding with Rhus corriaria but with root cuttings type. In Table 3 , Duncan's multiple-range test showed that the effect of the interaction between the IBA at $20000 \mathbf{~ m g . l ^ { - 1 }}$ and cutting diameter more than $1 \mathrm{~cm}$ increased the most cutting traits showing a synergistic effect as a result of the accumulation of the positive effect of each factor separately.

\section{CONCLUSION}

According to our knowledge, no sufficient information is found about the response of the C. coggygria to vegetative propagation. This study considered as an attempt to show how far the growth hormones and cutting size influence the rootabilty of this species. The results indicated that $C$. coggygria is relatively easy to propagate by stem cutting in comparing with $R$. corriaria. From the nurseryman's standpoint, the rooting percentage-of this experiment are of high importance since it exceed fifty percent which is a reasonable rate to produce cuttings economically, despite that, costs may be less important with endangered species as the case with $C$. coggygria. However, to meet a large scale demand and ensure easy supply of elite C. coggygria and $R$. corriaria seedlings further studies should be followed. Here, one can propose using stem cuttings with abundant bud numbers 
(cutting length) since, observationally in this study all roots initiated were from buried buds not from the cutting bases.

\section{ACKNOWLEDGEMENTS (OPTIONAL)}

We would like to thank the technical staff of the Forest and Rangeland - Duhok directorate for their assistance in the practical and financial issues of this study.

\section{REFERENCES}

Al-Rawe, K. M; Khalaf. M. (1980). Agricultural experimental design and analysis. National Library Foundation for printing and publishing, University of Mousl.

Barbuti, R., Mautner, S., Carnevale, G., Milazzo, P., Rama, A and Sturmbauer, C. (2012). Population dynamics with a mixed type of sexual and asexual reproduction in a fluctuating environment. BMC Evol. Biol. 12(1):49; DOI: 10.1186/1471-2148-12-49.

Burgess, D., Hendrickson, O., and Roy, L. (1990). The importance of initial cutting size for improving the growth performance of Salix alba L. Scand. J. Forest. Res. 5, 215-224.

Das, P; Basak, U and Das, A. (1997). Metabolic changes during rooting in pre-girdled stem cuttings and air-layers of Heritiera. Bot Bull Acad Sin .38:91-95.

Deepak, K.; Suneetha, G. and Surekha, Ch. (2015). A simple and effective method for vegetative propagation of an endangered medicinal plant Salacia oblonga Wall. J. Nat. Med. 70:115-119; DOI 10.1007/ s11418-015-0932-6.

Dirr, M.A. (1990). Manual of woody landscape plants: their identification, ornamental characteristics, culture, propagation, and uses. Champaign, IL: Stipes Publishing Company. $1007 \mathrm{p}$

Doroudi, H; Akbarinia, M; Jalali, S and Khosroujerdi, E. (2008). Effects of cutting diameter and media on rooting and survival of Sumac cuttings (Rhus Coriaria. L.). Iran J Agric Res; 21(2):271-277.

Dunn, D.E. (1999). Timing and auxin concentration affects Cotinus coggygria 'Royal Purple' rooting. Comb. Proc. Int. Plant Prop. Soc. 49: 510-513.

Edwards, R.A. and Thomas, M.B. (1980). Observations on physical barriers to root formation in cuttings. Plant Prop. 26:6-8.

Fogaça, C. M., and Fett-Neto, A. G. (2005). Role of auxin and its modulators in the adventitious rooting of Eucalyptus species differing in recalcitrance. Plant Growth Regul. $45,1-10$.

Foster., S, Stelzer., H and McRae, J. (2000). Loblolly pine cutting morphological traits: effects on rooting and field performance. New For., 89, 291-306.

Hannerz, M; Almqvist, C and Ekberg, I. (1999). Rooting success of cuttings from young Picea abies in transition to flowering competent phase. Scand J For Res, 14(6):498504.

Hartmann,T; Kester, E; Davies, F.T and Geneve, R.L. (2002). Plant Propagation Principles and Practices. 7 th Edition. Prentice Hall. New Jersey, pp. 367-374.

Husen, A. and Mishra, V.K. (2001). Effect of IBA and NAA on vegetative propagation of Vitex negundo L. through leafy stem cuttings from hedged shoots during rainy season. Ind. Perf., 45: 83-87.

Husen, A. and S. Khatoon. (2012). Role of anthraquinones as a marker of juvenility and maturity in response to adventitious rooting of Tectona grandis. Am. J. Plant Physiol., 7: 220-231.

Kaul, K. (2008). Variation in rooting behavior of stem cuttings in relation to their origin in Taxus wallichiana Zucc. New For. 36: 217-24.http://dx.doi.org/10.1007/ s11056-0089094-7.

Leakey, R and Mohammed, H. (1985). Effects of stem length on root initiation in sequential single-node cuttings of Triplochiton scleroxylon K. Schum. Hortic.Scie, 60,431437.

Leakey, R.R.B. (2004). Physiology of vegetative reproduction. In: Encyclopaedia of Forest Sciences (Eds. J. Burley, J.
Evans, and J.A Youngquist), 1655-1668, Academic Press, London, UK.

Leakey., R. (1983). Stockplant factors affecting root initiation in cuttings of Triplochiton scleroxylon K. Schum., an indigenous hardwood of West Africa. Hortic. Scie., 58,277-290.

Macdonald, B. (1986). Practical Woody Plant Propagation for Nursery Growers. Timber Press. Portland. Oregon.

Media, A. R. (2016) .Vegetative Propagation of Some Woody Species by Stem Cutting Using Indole Butyric Acid (IBA) and Rooting Media. Thesis. University of Duhok. Kurdistan region-Iraq.

Mohammadi, S., Kouhsari, S. M and Feshani, A. M. (2010). Antidiabetic properties of the ethanolic extract of Rhus coriaria fruits in rats. Daru. 18(4):270- 274.

Muhamed, H and Sarhan, N (2016). Effect of root cutting diameter, length and indolebutyric acid concentrations on the rooting ability and growth of (Rhus coriaria L.) Root cuttings. Agri. and Vet.Sciences 19, (1), Pp 257-266.

Newman, J. P. (2014). Container Nursery Production And Business Management Manual.p124., UCANR Publications.

Nokes., J. (1986). How to grow native plants of Texas and the Southwest. Texas Monthly Press, Inc., Austin.404 pp.

Ogle, G.; Hoag, J. and Scianna, J. ( 2000). User's guide to description, propagation and establishment of native shrubs and trees for riparian areas in the Intermountain West. Tech. Notes Plant Materials 32. Boise, ID: U.S. Department of Agriculture, Natural Resources Conservation Service. 22 p.

OuYang, F; Wang, J and Li, Y. (2015) Effects of cutting size and exogenous hormone treatment on rooting of shoot cuttings in Norway spruce [Picea abies (L.) Karst.]. New For 46:91-105.

Özkaya, MT; Celik, M and Algan, G. (1998). Anatomy of Adventitious Root Formation in Stem Cuttings of the Easy-to-Root (GemlíK) and Hard-to-Root (Domat) Olive Cultivars. Progress in Botanical Research. pp 435-438

Pacholczak, A., Ilczuk, A., Jacygrad, E and Jagiełło-Kubiec E. (2013). Effect of IBA and biopreparations on rooting performance of Cotinus coggygria Scop. Acta Hortic., 990: 383-389.

Palanisamy, K and Kumar, P. (1997) Effect of position, size of cuttings and environmental factors on adventitious rooting in neem (Azadirachta indica A. Juss). For Ecol Manag, 98(3):277280.

Porter, Y.V. (1963). The effect of cyclic lighting and growth regulators on the rooting of Rhus lancea cuttings. Thesis. University of Arizona.p:36. http://hdl.handle.net/10150/551657.

Saifuddin, M., Normaniza, O. \& Rahman, M.M. (2013). Influence of different cutting positions and rooting hormones on root initiation and root-soil matrix of two tree species. International Journal of Agriculture and Biology, 15:427-434.

Shahbaz S. E. (2010). Trees and shrubs. A field quite to the trees and shrubs of Kurdistan region of Iraq. University of Duhok Publication, UoD Press. 602: 283-285p.

Shahbaz, S. E. (2012). Endangered plants of Kurdistan. Kurdish Academy, Hawler, Kurdistan.

SAS Institute Inc. (2001). SAS Online Doc, version 9.1.3. [Online document]. Available at: http:// support.sas.com/onlinedoc/913/docMainpage.jsp.

Tchoundjeu, Z and Leakey, R. (1996). Vegetative propagation of African mahogany: effects of auxin, node position, leaf area and cutting length. New For. 11(2):125-136.

Tipton; J.L. (1992). Requirements for seed germination of Mexican redbud, evergreen sumac, and mealy sage. Hortic Sci. 27(4): 313-316.

Tracz., T. (1983). In: Alexander., J and Koller G.(moderators). New plant forum. Combined Proc. Int j plant sci. Combined Proceedings, 33, $489-490$.

Tsankova, E.T; Dyulgerov, A.S and Milenkov, B.K. (1993). Chemical composition of the Bulgarian sumac oil. J Essent Oil Res. 5: 205-207

Vigl., F, and Rewald., B. (2014). Size matters? The diverging influence of cutting length on growth and allometry of two Salicaceae clones. Bio. Bioe., 60,130-136.

Wilson, J and Grange, R. (1983). Regeneration of sclerenchyma in wounded dicotyledon stems. Ann. Bot. 52, 295303.Abstract/FREE Full Text Google Scholar.

Yong, kweon Y and Ki, sun K. (1996). Seasonal variation in rooting ability, plant hormones, carbohydrate, nitrogen, starch and soluble sugar contents in cuttings of white forsythia. J. Kor. Soc. Hort. Sci 37(4):554-560. 
كارتيكرنا تيرايتا هرمونى ترش اندول بيوتريك (IBA) و ستويراتيا قهلميّن جه قى لسهر رويهدانين وشينبونا قهلمين سماقي Rhus coriaria و و كوتينوسى

كورتيا ليّكولينى:

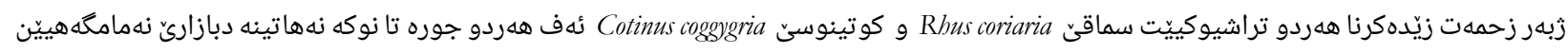

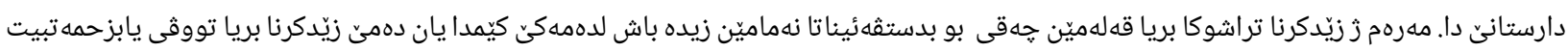

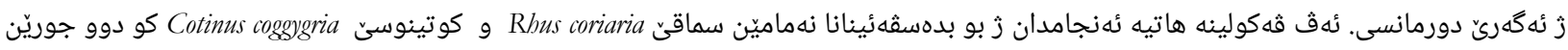

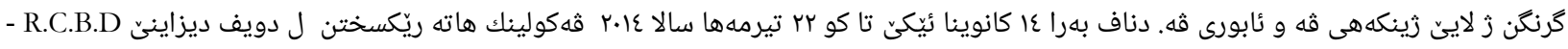

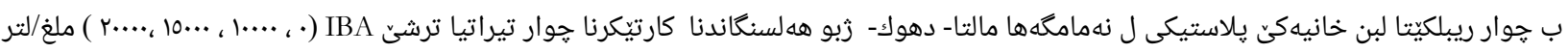

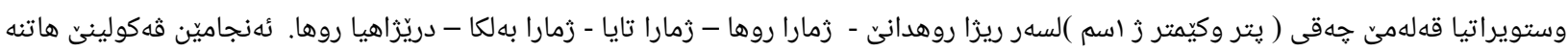

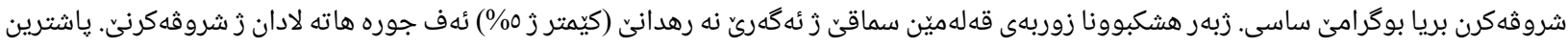

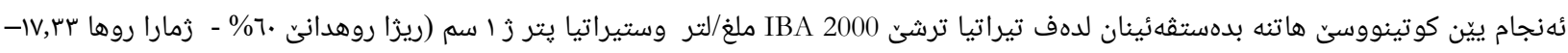

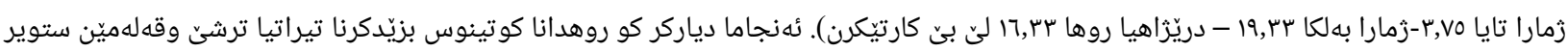

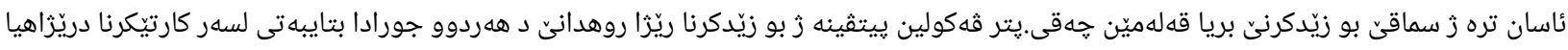

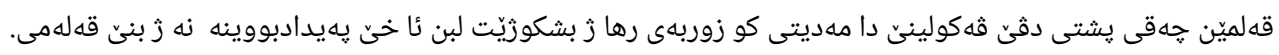

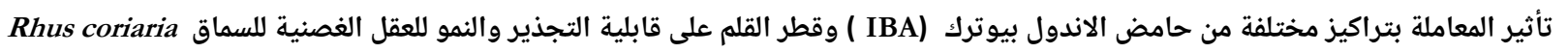

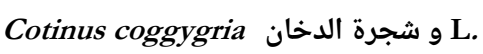

خلاصة البحث:

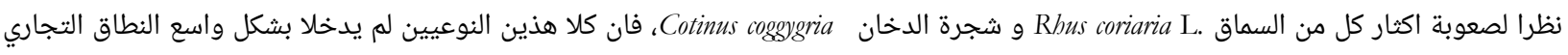

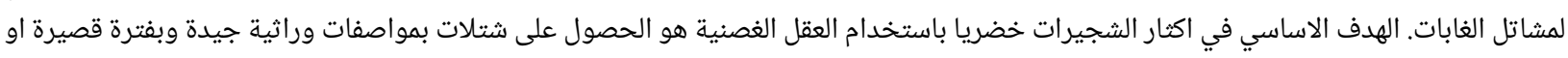

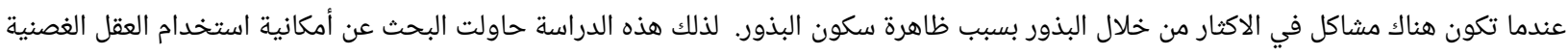

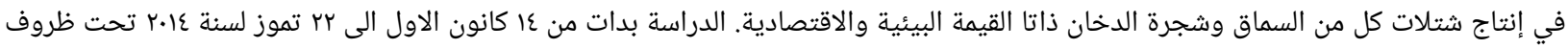

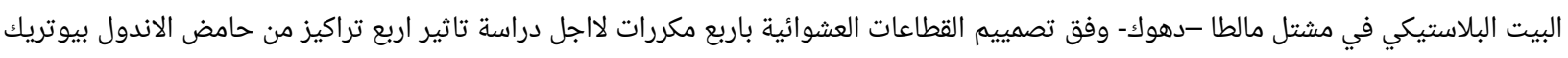

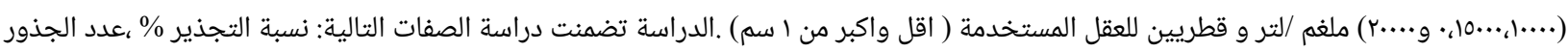

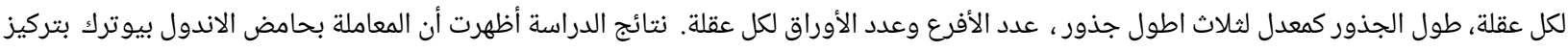

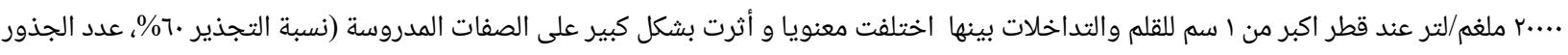

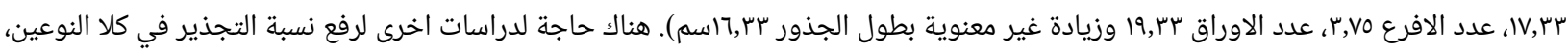

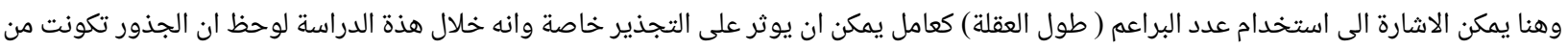
البراعم المدفونة بالتربة وليس من قواعد الاقلام. 